\title{
The great crusader hero
}

\section{Louis IX or Joinville?}

\section{Adriana Almeida}

\section{OpenEdition \\ Journals}

\section{Electronic version}

URL: http://journals.openedition.org/medievalista/4379

DOI: 10.4000/medievalista.4379

ISSN: 1646-740X

\section{Publisher}

Instituto de Estudos Medievais - FCSH-UNL

\section{Electronic reference}

Adriana Almeida, "The great crusader hero", Medievalista [Online], 4 | 2007, Online since 05 March 2021, connection on 25 March 2021. URL: http://journals.openedition.org/medievalista/4379; DOI: https://doi.org/10.4000/medievalista.4379

This text was automatically generated on 25 March 2021.

\section{(). (1) (8)}

Mediavalista está licenciado com uma Licença Creative Commons - Atribuição-NãoComercial 4.0 Internacional. 


\title{
Louis IX or Joinville?
}

\section{The great crusader hero}

\author{
Louis IX or Joinville?
}

\section{Adriana Almeida}

1 Joinville's Vie de Saint Louis is, in the least, a touching account of a hard campaign in the East, and the humanity and sanctity of a king. There are countless ways in which the reader can be touched, though, from excitement at battle descriptions, tenderness at the goodness of King Louis IX, or annoyance prompted by the imposing presence of the narrator himself. This essay seeks to study the author's relation to the ideals of chivalry as exposed in Joinville's work, and try to understand, if possible, who is the real hero in the Vie de Saint Louis.

2 In the Dedication to the future Louis X, Joinville claims to have written the book at the request of his mother, Queen Jeanne de Navarre, to put down in writing the pious saying and the good deeds of our King, Saint Louis', ${ }^{1}$ illustrating the sanctity of the monarch. Clearly, Joinville had this appeal in mind when he composed the chapters that open and close the work. ${ }^{2}$ In these, the reader is overwhelmed with the pouring of qualities, exemplar deeds, advice and acts of capable administration of the kingdom by his beloved king. There is hardly any narration, and all there is is subject to the purpose of illustrating the attributes of the monarch. The facts enumerated have little or no logical relation between them. In Chapter One of the first part, for instance, from an advice of the King on how people should dress we jump to an anecdote about King Louis questioning Joinville on his idea of God, and then to an episode in which the monarch warns our writer to follow Christ's example and wash the feet of the poor. ${ }^{3}$ The ending chapters, although of the same nature, offer a somewhat more organized division of the sketches: 'his wisdom', ${ }^{4}$ administration of the realm, ${ }^{5}$ or patronage and piety. ${ }^{6}$

3 The Chapters in the middle (Part Two, Chapters Two to Seventeen), which represent most of the book, make up a narrative, with beginning, development, and ending. The frontiers between the parts may vary depending on what we consider to be the main plot, if the crusader adventure of the main characters, the development of the friendship between Joinville and Louis, or any other, but establishing these boundaries 
is not a concern in the present essay. Trying to define the plot itself is, however, and this will be looked into below. The setting is King Louis's first crusade, but, although the monarch figures greatly in it, and unlike what happens in the opening and ending chapters, ${ }^{7}$ he is not the main character.

4 For now it will be enough to emphasize that the Vie de Saint Louis does not therefore seem to be a single piece, as some have argued, but to comprehend instead two different elements, written at different times: an apologia of the goodness and sanctity of King Louis, composed in the early fourteenth century, and a much earlier account of his first crusade. ${ }^{8}$ These sections are different from each other not only in style, but also, as Caroline Smith explains, in proportion, in the vocabulary, and in the narrator's stand towards knightly behaviour and values. ${ }^{9}$ Concerning proportion, we have seen that the middle section, which concerns the six-year crusade, is much larger than the rest of the work, which intends to cover the rest of the fifty-six years of Louis's life. Nonetheless, the incidence of words connected to 'saint' and 'sanctity' used in relation to the king is, in the biographical chapters, seven times higher than in the crusading ones..$^{10}$ As regards knightly values and behaviour, Joinville seems to be of different minds in the two sections. If in the crusading account his enthusiasm of knightly display and bravado is evident, the Joinville of the biographical chapters openly criticises the contemporary values of the knightly class, particularly in what concerns expenditure with fashion and display. ${ }^{11}$ If, on the one hand, he identifies a change in the values of his peers, more concerned with displaying beautiful outfits than good Christian qualities, ${ }^{12}$ there is a natural change in Joinville's own viewpoint - the older Joinville was, I believe, closer to the man he admired, as we will see below.

5 Assuming that the book includes indeed two different parts and that they were written probably several years apart, ${ }^{13}$ the purpose stated by the author in the Dedication is not necessarily valid for both of them. In my view, an analysis of the characters in the crusading narrative will show the purpose to be applicable only to the opening and closing chapters. In the latter, the main character is King Louis, of which all others, including the narrator, seem to be subsidiary. In the crusading section, however, he appears to have a different role, subsidiary in its turn to that of Joinville.

6 The crusading narrative starts in Chapter Two of the second part, with an account of the events surrounding the king's decision to go on crusade: his serious illness, miraculous recovery and spontaneous vow. ${ }^{14}$ This introduces the context of the story, taking the reader to Joinville and his preparations for the crusade. The king is referred again when he calls his barons to Paris to pay homage to his children, and regarding a case the Provost of the city took to his consideration. However, and even though the latter episode does give evidence for the wisdom of the king, both references are here but secondary, as they are introduced in some connection to the person of Joinville, either to show him as one of the barons called on, or simply because he came across the second story. Considering that this link to the narrator may be a literary device to introduce the issue only strengthens Joinville's role as the main character.

7 The relation between the characters exemplified in this chapter is reproduced, in my opinion, in the whole crusading section: Joinville is the main character, and it is his own crusading adventures that he tells about. Louis's role is both subsidiary to Joiville's and very important to the story. On the one hand, Joinville likes to flaunt his privileged position in the King's consideration and esteem, in the same way he delights in referring the connection, either by blood or marriage, between himself and important 
people he mentions, such as the Comte de la Marche, the Comte de Soissons, or the Emperor of Germany. ${ }^{15}$ On the other hand, and more importantly, he feels true love and admiration of the King. Although in the foreground of the story are the opinions, actions and deeds of Joinville, they are set against a background of Louis's opinions, actions and deeds. The King's role in this plot is, therefore, not one of a hero, but one of a model.

8 Along his account, Joinville mentions many of his peers, admiring their feats, their valour, audacity or wisdom, and often offers a sample of their knightly career, either during the crusade venture or not, perhaps to cause equal delight and admiration in the reader. Such are the cases of Gautier d'Autriche, who set alone against the Muslims but was thrown off his horse and beaten, ${ }^{16}$ or Josserand de Brancion, whom he commends as 'one of the best knights in the army', and admired not less for his piety than for his competence on the field. ${ }^{17}$ Occasionally he admires the fighting in itself, without distinguishing sides. For instance, under the day of the Battle of Mansourah, we can read about the knights of the king's entourage and their Muslim opponents: 'It was, I can assure you, a truly noble passage of arms, for no one there drew either bow or crossbow; it was a battle of maces against swords between the Turks and our people, with both sides inextricably entangled'. ${ }^{18}$

There is no one, however, for whom he shows more admiration than for the king himself. Louis gathers all the qualities of the ideal Christian ruler. In the portrait Joinville makes of him, he resembles that of Charlemagne in La Chanson de Roland. This mighty Christian king, the ultimate standard of the faith, is portrayed in the old French chanson de geste as pious, just and strong, a powerful, charismatic leader, who, yet, will sit on the grass to confer with his council of Twelve Peers, whom he loves as a father his sons. ${ }^{19}$ Joinville's portrait of King Louis is based on the same qualities. The King has a council of nobles, to whom he listens frequently, consulting them in matters ranging from whether to stay in Cyprus waiting for the troops still at sea, or leave immediately for Egypt, to advice on changing of tactics in the middle of a battle. ${ }^{20}$ There is no comparison to the king's generosity, not only to the poor and clergy but also to his peers, whom he often invites to his table and rewards with gratifications and offices. ${ }^{21}$ He is wise in his decisions and advice, showing himself both sensible and sensitive, as for instance when he accepts the advice of Joinville, the Comte de Jaffa and Guillaume de Beaumont of not leaving for France until all the prisoners were ransomed. ${ }^{22}$ Several episodes in this account attest the French monarch's devotion and purity of mind - his discharging from his service men that had consorted with prostitutes in the vicinity of his own pavilion. ${ }^{23}$ Other attributes account for his portrayal as the perfect ruler, namely his dubbing a young men knight, ${ }^{24}$ and, mainly, courage and determination, along with his feats of arms. This is when the younger Joinville's admiration for the king reaches its highest peaks, when he jumps in the water to join his men and his standard on the shore, ${ }^{25}$ or descends upon the enemy surrounding his brother in order to rescue him. ${ }^{26}$

10 However, there are some 'knightly values' the younger Joinville who writes the crusader account admires in some of his peers, and that he will not find in his king. Such are acts of reckless courage, as the above mentioned gesture by Gautier d'Autriche of attacking the Muslims single-handed and the impetus of the Comte d'Artois towards Mansourah that led to his death, or the fanciful display of status and glory, as favoured by the Comte de Jaffa, both for his castle ${ }^{27}$ and his ship, which is described thus 
11 His galley was covered, both under and above the water, with painted escutcheons bearing his arms, which are or with a cross of gules patée. He had at least three hundred rowers in his galley; beside each rower was a small shield with the count's arms upon it, and to each shield was attached a pennon with the same arms worked in gold. ${ }^{28}$

12 King Louis always dressed simply, and preferred spending his money on charity or patronage than on himself or such vain display. "He often said that people ought to clothe and arm themselves in such a way that men of riper age would never say that they had spent too much on dress, or young men say they had spent too little'. ${ }^{29}$ Regarding the individual efforts of knights to show their courage and ability, Richard Barber tells us they constituted the greatest weakness of a medieval army. ${ }^{30}$ Impetuous knights made an unreliable force for a ruler, and King Louis reaction of impatience or irritation to Gautier d'Autriche's and other such gestures confirms this. ${ }^{31}$ The King corresponds to the model of knight Joinville comes to admire in his older age, when he writes the biographical chapters of the Vie, and, in my opinion, he manages to come closer to that paradigm. To the ideals of his younger self, however, he, Joinville, is perhaps closer to the ideal chevalier than Louis.

13 Joinville had his knightly education at the court of Thibaut IV, Comte de Champagne, and later King of Navarre. This was a literary court, in which the count himself revelled and rivalled in the minstrel's arts. Surely such an environment was the place to foster the classic virtues of chivalry already established in the works of Chrétien de Troyes in the second half of the twelfth century. ${ }^{32}$ These, as listed by Maurice Keen were prouesse, loyauté, largesse, franchise and courtoisie. As we shall see, the young Joinville portrayed in his own words matches all these features. He describes his own deeds in the same casual but enthusiast way he uses for the feats of others, and it seems to me that those attitudes are natural and genuine of him, and not affected.

Joinville's enthusiasm with all he perceives as knightly display and behaviour on the part of his peers can be justified, not only by his education at the court of Champagne and his own character, and perhaps by the relative young age and little previous experience on the battlefield. When he left France for the East, in 1248, he should be about twenty-three years old, ${ }^{33}$ and, according to Smith, his only experience of war before this date was is a private campaign of his uncle, the Comte de Chalon. ${ }^{34}$ Before his fostering at the court of Count Thibaut, he had grown up listening to the crusading adventures of almost all the men in his family: his grand-father, his father and two of his uncles. If would be only natural that, at that age, he would want to copy the feats, not only of the heroes of chansons de geste and romances he probably heard at Champagne, but also his lineage.

Prouesse is shown by Joinville on several occasions on the battlefield, although his actions cannot always be distinguished from those of his men. As soon as he sets foot on Egypt with a few of his people, but 'neither squire, nor knight', he withstands an attack of the enemy ${ }^{35}$ On Christmas Day 1249 they rescued a fellow knight from Muslim hands during an attack. ${ }^{36}$ For the day of the Battle of Mansourah, he tells us 'I and my knights had decided to go and attack some Turks who were loading baggage in their camp'. Even his frequent admissions to pain and fear do not blemish this courage. Roland would never admit to such thing, of course, but this is not a chanson de geste, in spite of all the influences it shows. ${ }^{37}$ Joinville may present all the qualities of a knight, but he also shows frailties in all of them, which makes the account all the more real to 
his reader and audience, and the hero, Joinville, human, and attainable as example of conduct.

It is similar in what concerns loyauté. Several episodes show Joinville's absolute loyalty to his king and to his fellow Christians, and his humility in accepting rebukes from his superiors and elders. His loyalty to his fellows cannot be better illustrated than by his refuse to leave for France while there are still Christians held hostages. ${ }^{38}$ The faithfulness to his friend and king seems harder to pinpoint in an episode for it trespasses all his relation with Louis. Perhaps it can be best exemplified by Joinville's own suggestion, and eventual execution, of forcing the Templars to surrender the money they had in they charge, in order to ransom the king's brother. This went against his values, and he tries to make it as honest and open as possible, even asking the high officers of the Temple to be witnesses to his deeds. The episode, culminating in a reaction of immense satisfaction of the king, was a sacrifice of character by Joinville to serve the best interests of Louis. ${ }^{39}$ Similarly to what was illustrated above, there can be seen slight breaches in this loyalty, in the form of disobedience, as when he says that, on first landing in Egypt, from the ship of the king they 'told me to land beside the standard of Saint Denis ... However, I paid no heed to them, but on the contrary landed my men in front of a great body of Turks', without even giving a reason for this to his reader or audience. ${ }^{40}$

Joinville's largesse is also frequently illustrated. He assumes the sustenance of the knights he takes with him ${ }^{41}$ feeds at least part of his knights at his table, ${ }^{42}$ and even pardons a servant an amount he has stolen from him..$^{43}$

His franchise is perhaps the most remarkable of Joinville's features. His every gesture appears to show the genuine and spontaneous openness of someone who has got nothing to hide. His frankness in speech may sometimes be taken for rashness, but nevertheless, he speaks his mind to peasant and king. Occasionally, however, his actions reflected and purposeful to avoid suspicion or rumour, as when he makes sure that his bed is visible from the door of his tent 'to prevent anyone harbouring evil suspicions of me with regard to women'.

19 And, a propos, we get to the last classic asset of the virtuous knight: courtoisie. Joinville is, in general, courteous to all those surrounding him, and only on occasion reveals particular courtesy towards ladies, proper of his courtly upbringing. This happens, for instance, when he supplies with cloth the Empress of Constantinople, after she was left ashore without any clothe change, by accident. ${ }^{44}$ Further mentions of ladies regard particularly the Queen, Louis's wife, Margaret de Provence, towards whom he shows reverence and friendship. He tells us how brave, strong, generous and pious she showed herself in Damietta, moreover, having just given birth. After the king's troops' defeat she had to hold the men of the Italian Republics, probably the only ones capable of guaranteeing the defence of the city, so that she could exchange it for the king. ${ }^{45}$ When, later in the story, the Queen goes to join the king in Saida, after her latest confinement, it is Joinville who goes down to the port to meet her. On his return to the king, whom he finds in the chapel, the latter asks about his wife and children, mentioning them to Joinville for the first time in the five years they have known each other. This apparent indifference shocks Joinville, who says that 'it does not seem right and proper for a man to be so detached from his own family'. ${ }^{46}$ This takes us to a question which has often made readers wonder: when leaving his land for the crusade Joinville declares he cannot look back 'for fear my heart might be filled with longing at 
the thought of my lovely castle and the two children I had left behind'. There is no mention of his wife, although he is still married and only dies about $1260 .{ }^{47}$ This may seem incongruent in face of his criticism of the king for not demonstrating his affection for his family. And strange, for Jonville's work not only reflects the knightly values of his upbringing, as we have been analysing, as draws on various contemporary literary styles, as Caroline Smith convincingly argues, among which are crusader songs. Contemporary crusader songs, in which the pain of leaving home is frequently dealt with, usually refer a wife or lover, even if for convention sake. Take, for instance this one by Conon de Béthune (d. c. 1220), which begins

Ahi! amours, con dure departie

Me convendra faire de la meillour

Qui onques fust amee ne servie! ${ }^{48}$

Or one by the Chatelain de Coucy (d. 1203), who complains

A vous, amant, plus k'a nulle autre gent,

Est bien raisons que ma doleur conplaigne,

Quar il m'estuet partir outreement

Et dessevrer de ma loial conpaigne

...

Biauz sire Diex, qu'iert il du consirrer

Du grant soulaz et de la conpaignie

Et des douz moz dont seut a moi parler

Cele qui m'ert dame, conpaigne, amie? ${ }^{49}$

It is unlikely that a lack of affection between Joinville and his first wife would by itself justify the omission, and, in the context of the chivalric culture so dear to him, the gesture may seem precisely the opposite of courtois, even if she was not his 'compaigne, amie'. However, if we put the composition of this part of the Vie back to the years between 1261 and 1290, there may be a chance that this omission is precisely a gesture of courtesy of Joinville to his second wife, whom he married in the first date, and seems to have died around $1288 . .^{50}$ This would be more consonant with what he seems to think proper in the relation of a couple. His views on this subject are hinted at when he refers to the way in which the Queen-Mother, Blanche de Castille, did not let the king and his wife be together 'except when he went to sleep with her at night', and describes Louis and Margaret as a pair of lovers, stealing away to meet in secret in covert places. In this view, and given that the couple managed to have three children during the hectic six years of their crusade, this may have sometimes felt to them as a sort of honeymoon.

In conclusion, the central part of the Vie Saint Louis has a different structure and purpose from the opening and closing chapters, and may be read as a narrative in itself, whose hero is Joinville himself. Throughout the text, he shows awe and delight for all facets of knightly behaviour, from solidarity on the battlefield, to piety or a glorious display of heraldry, possibly influence of his upbringing in a particularly chivalric court as that of Thibaut de Champagne, and also due to his relative youth and inexperience in war. His youthful admiration found in King Louis a model of chivalric behaviour and, mainly of Christian leadership, particular impressive to Joinville's eyes for his deep piety, endless generosity and great wisdom. Some of the aspects of chivalry most fascinating to the young Joinville, as the rich display and the daring individual feats, however, are not looked upon with favour by the king, and Joinville himself sometimes seems closer to his own ideal of knight than the figure of the king. Joinville's personal chivalric values appear to have changed later on in life, when writing what would be the biographical chapters of his work, to a viewpoint more similar to that of the king. 
He no longer admires rashness and ostentation, and looks more fondly on the simplicity and humility of his King Louis, now lost in his heirs.

\section{BIBLIOGRAPHY}

Barber, Richard, The Knight and Chivalry, London, Cardinal, 1974, $1^{\text {st }}$ ed., 1970.

Dijkstra, C.Th., La chanson de croisade : étude thématique d'un genre hybride, doctoral thesis published online, University of Groningen, 1995. http://irs.ub.rug.nl/ppn/142034533.

Joinville, 'The Life of Saint Louis', in Joinville and Villehardouin: Chronicles of the Crusades, ed. by B. Radice and R. Baldick, trans. by M. R. B. Shaw, Harmondsworth, Penguin Books, 1970, $1^{\text {st }}$ ed. 1963.

Keen, Maurice, Chivalry, New Haven, Yale University Press, 1984.

Mémoires de Jean, Sire de Joinville, ed. by Francisque Michel, with essays by Ambroise Firmin-Didot and Paulin Paris, Paris: Librairie de Firmin-Didot, $1880,4^{\text {th }}$ edt..

Smith, Caroline, Crusading in the Age of Joinville, Hants, Ashgate, 2006.

The Song of Roland, ed. by B. Radice, trans. by D. L. Sayers Harmondsworth, Penguin Books, 1977

\section{NOTES}

1. Jean de Joinville, 'The life of Saint Louis', in Joinville and Villehardouin: Chronicles of the Crusades, ed. by B. Radice and R. Baldick, trans. by M. R. B. Shaw (Harmondsworth: Penguin Books, 1970, $1^{\text {st }}$ ed. 1963), p. 163. For convenience I shall be citing this edition instead of the original in Mémoires de Jean, Sire de Joinville, ed. by Francisque Michel, with essays by Ambroise Firmin-Didot and Paulin Paris (Paris: Librairie de Firmin-Didot, $1880,4^{\text {th }}$ edt.); both have been consulted.

2. By these I mean Chapters One and Two of Part One and, of Part Two, Chapters One and Eighteen; Chapter Nineteen concerns the King's second taking of the cross (and Joinville's motives for not going), but include Louis's last words to his son, which are part of the apologia that characterizes the referred chapters; the last chapter, Twenty, has a different structure, being a very brief summary of the canonization process of the king.

3. Joinville, pp. 168-9.

4. Ibidem, pp. 331-6.

5. Ibidem, pp. 337-42.

6. bidem, pp. 342-4.

7. From here on I shall refer to the beginning and ending chapters, which concern King Louis's life and deeds as 'biographical', for convenience.

8. The discussion on the unity or not of the piece of work and the time of composition of the Vie de Saint Louis is well exposed by Smith, pp. 48-57. I entirely agree with her view and arguments.

9. Caroline Smith, Crusading in the Age of Joinville (Hants: Ashgate, 2006), pp. 54-6.

10. Definite study by Elisabeth Gaucher, referred to by Caroline Smith, p. 56.

11. Smith, pp. 54-5. 
12. Joinville, pp. 165, 168, 352.

13. See n. 8 , above.

14. Joinville, p. 191.

15. Ibidem, pp. 191, 224, 245.

16. Ibidem, p. 208.

17. Ibidem, pp. 233-4.

18. Ibidem, p. 222.

19. The Song of Roland, ed. by B. Radice, trans. by D. L. Sayers (Harmondsworth: Penguin Books, 1977), pp. 55, 57-8, 72, 77, 81, 84 .

20. Joinville, pp. 197, 222.

21. Ibideme, pp. 198, 273, 290

22. Ibidem, p. 269.

23. Ibidem, p. 207.

24. Ibidem, p. 296.

25. Ibidem, p. 204.

26. Ibidem, p. 232.

27. Ibidem, p. 295.

28. Ibidem, p. 203.

29. Ibidem, p. 168.

30. Richard Barber, The Knight and Chivalry (London: Cardinal, 1974, $1^{\text {st }}$ ed., 1970), p. 196.

31. Joinville, pp. 208-9. Later on the venture, maybe having learned from experience or from the example of the King, Joinville himself does not look so kindly or excitedly on individual displays of prouesse, revealing even some unexpected coldness. See Joinville, p. 309

32. Maurice Keen, Chivalry (New Haven: Yale University Press, 1984), p. 2.

33. Smith, p. 47.

34. Ibidem, p. 176.

35. Joinville, p. 203.

36. Ibidem, p. 214.

37. For this, see Smith, pp. 61-3, 65-71. For the difference in Joinville's acknowledgement of pain, see p. 133-4.

38. Joinville, pp. 269-70.

39. Ibidem, pp. 258-9.

40. Ibidem, p. 203.

41. Ibidem, pp. 192, 198 .

42. Ibidem, for instance, pp. 291, 313.

43. Ibidem, p. 268.

44. Ibidem, pp. 198-9.

45. Ibidem, pp. 262-3.

46. Ibidem, p. 213.

47. Smith, p. 180.

48. RS 1125, Lerond 1964:187, in Dijkstra, C.Th., La chanson de croisade : étude thématique d'un genre hybride, (doctoral thesis published online, University of Groningen, 1995

http://irs.ub.rug.nl/ppn/142034533)

49. RS 679, Lerond 1964:57, in Dijkstra, p. 177.

50. Ambroise Firmin-Didot points at this date in his 'Sur la chronologie des Sires de Joinville', in Mémoirs, p. 225. In 'Actes et documents concernant les Sires de Joinville', by the same author, there is a charter of Joinville, dating of 1290 , whereby he endows the church of Benoitevaux with 
a fair amount of wax so that each year, as a mass is sung, candles are lit 'est mis aux pieds de la tombe de ma bonne compaigne Alis, dame de Joinville et de Risnel', in Mémoirs, p. 197

\section{AUTHOR}

ADRIANA ALMEIDA

Aluna de Mestrado da Faculdade de Letras do Porto 